\title{
Social Investment by PSUs in North East region of India
}

\author{
* Dr. O. P. Singh \\ **Ms. Pragya
}

\section{Abstract}

Corporate social responsibility has gained much importance in the changed business environment in India. A large number of big corporate houses have set up their Trust and Development Foundations for initiating CSR activities. Even some of the Corporate Houses embarked upon corporate social responsibility initiatives and at the later stage, they developed a full-fledged institute / organization committed towards social development. There has been a progressive increase in social investment by the Corporate Houses in the country. Large MNCs like Tata Group, ITC, Ranbaxy, Infosys, Microsoft, Dr. Reddy's Laboratory, etc. have endeavored to create a better social order by investing hugely in social development. However, Tata Group has emerged to be the pioneer in the field as it has comparatively larger social investment. A number of institutions and social development organizations are being supported by Tata Group in the field. The present paper highlights the CSR spending by PSUs in north east region of India.

Keywords: Social Investment, PSU, CSR Activities

\section{Introduction}

North-East India, homeland to Mongoloids, has been a great cross road, its valleys and passes being witness to centuries of migration as tribal communities have moved to seek new homes. It has been a gateway of commerce and culture that linked overland East and South-East Asia. The partition aggravated its geo-political isolation even as rising ethno-cultural consciousness among its extra-ordinarily varied population and migrant pressures have given

*Associate Prof. Deptt. of Community Medicine and Public Health, King George Medical University, Lucknow

** Assistant Prof. , Faculty of Management Studies, Assam University, Guwahati, Assam 
rise to tensions and violence situated in a long troubled and uncertain neighborhood embodied in civil strife and known for its war roads, drug mafia and arms bazaar, the North-East could hardly remain immune to these baleful influence. The North-East India comprising of Sikkim, Assam, Meghalaya, Arunachal Pradesh, Nagaland, Manipur, Mizoram and Tripura, is spread over an area of about 265,000 sq.km., representing roughly 8 per cent of the country's total area and approximately 4 per cent of its population. Of the 5653 communities, 635 are tribal, while a little over 200 are found in the North-East. The population in most of the states of North-East is predominantly tribal, variations ranging from 22 to 30 per cent in Sikkim and Tripura and 63 to 94 per cent in Arunachal Pradesh and Mizoram respectively. The tribal population of Assam is $12.82 \mathrm{per}$ cent but is numerically larger touching.

The footprints of CSR programmes are now extended to the remote and backward areas even in the North-East region. The PSUs prefer CSR funding for the development and welfare of marginalized communities under CSR initiatives. A large number of tribal and ethnic groups reside in North-East region and therefore PSUs prefer CSR funding in North-East region. However, due to insurgency, the CSR initiatives by public sector units have suffered in some of the states mainly in Assam. PSUs have their own mandate of CSR in their CSR policy as well as in their philosophy of business. However, conservation of cultural heritage, environment protection, and health care, sanitation and infrastructures development in rural areas are the preferred areas of CSR intervention. The Government of India has already provided the national priority areas for social investment by the PSUs, corporate houses and business firms. Thus, Central PSUs and business firms prefer to support state government in achieving the goals under national priority areas such as sanitation, and infrastructure development in rural areas to strengthen delivery of health care services. Business houses in India are taking voluntary sustainability measures evolving into sustainable enterprises. These include reduction in carbon emission, promotion of renewal and nonconventional energy resources, construction of green building and infrastructure, development of innovative fuel efficient vehicles, 
promotion of eco-friendly products and packaging, organic farming and environmental protection. Besides, corporate houses are adopting inclusive policies for human resource development and welfare of the families of their employees.

The business organizations have developed a variety of strategies for dealing with the inter-section of societal needs, natural environment, and the corresponding business imperatives. Thus, corporate responsibility is a prime phenomenon of business and society. There is increasing interface with business organizations and community for societal development. The close link between a corporation and community creates sustainable development. CSR projects give aids to local organizations and marginalized communities. The societal perception on CSR activities of business is changing. The liberalization of economy has reduced the regulatory framework imposed by the state. However, self regulation by business has increased in the changing business environment. There is major focus on bottom of the pyramid principle initiated by management Guru C.K. Prahalad that corporate houses have to substantially investment on social development in order to penetrate their products and services and sustain their customer base. The business is no longer viewed as selfish endeavor of profit maximization. Society takes a positive view of their actions and expects a responsible and ethical behavior. Thus, the process of integration of the society and business has began a business has to reinforce the positive momentum to strengthen the confidence and trust in the society.

The theme of corporate social responsibility assumes pivotal significance in today's changing business environment. Contribution to sustainability in the economic development is one of the major commitments of a business. Historically, the concept of corporate social responsibility is very old. However, in India it has undergone a long journey from philanthropy to public-private people partnerships. The social investment and initiatives by some of the corporate houses in India are beyond the corporate governance as a large chunk of deprived, vulnerable, poor and backward population and areas are being benefited by them directly and indirectly. While 
corporate governance is about promoting corporate fairness, transparency and accountability, the social investment by corporate houses have improved its overall brand image and business performance.

Gulati (2005) is of the view that the social aspects of sustainability has closely linked with the impact of organization's activity on society, including employees, customers, community, and supply chain and business partners. Social performance supports the organization's ability to deliver high quality environmental and economic performance. CSR has focused hot spots for developmental issues at different times across India. The major priority areas of CSR initiatives have been environment conservation, health, education, livelihood development and women empowerment. The government is also encouraging CSR initiatives as it has already enacted national policy on CSR while the networking of NGOs and other stake holding agencies gives much impetus to CSR activities.

The term of corporate social performance was first introduced by Sethi (1975), elaborated by Carroll (1979), and developed by Wartick and Cochran (1985). Sethi (1975) gave the concept of corporate social performance in his three-level model. Sethi's three level models were social commitment, social responsibility, and social awareness (Cochran, 2007). During the past few years it was observed that the business organizations have shifted their focus from conventional philanthropically and charitable activities to a wider arena, particularly all those aspects which affect the business environment directly or indirectly, e.g. internal and external stakeholders, environment, concern for disadvantaged groups in the society. etc. This has been driven both externally by increased public and governmental expectations and internally by corporate inclination (Mohan, 2001). 


\section{Evolution of CSR}

CSR is a relatively recent phenomenon. However, owners and managers of firms were engaged in such activities which are now called as CSR almost from the beginning of the industrial revolution. The activities today regarded as societal concerns were integral to production during the late 18 th century, thus, the owners found that they had to provide for the efficient transport of raw materials and products beside labor welfare measures. Moreover, they found problems of workers such as lack of discipline, laziness, drunkenness, punctuality, and difficult to manage them (Pollard, 1965). Business owners often helped in developing roads and canals and supported other groups interested in the issues such as education of workers and their children. The factory owners also build housing estates for factory workers. The owners were happy to extend support for moral education to make the labor disciplined and punctual. The owners also provided support for the efforts of churches and evangelists to change the moral codes of laborers outside the workplace. Gradually, state started to develop transportation facilities and the industrialists stopped construction of roads and canals. The need to provide housing to factory workers also declined over the period as industries and factories moved to urban centres. Even though owners often have provided housing and community services. During the late 19 th and early 20 th centuries, a wave of extra-local philanthropy emerged as forerunner of CSR. John Rockefeller provided the funds for creating the University of Chicago while and Andrew Carnegie was instrumental in funding public libraries in many communities across the country. Carnegie also provided the funds for faculty pension university colleges.

By the 20th century "welfare capitalism" gained importance and companies provided extensive community facilities and labour welfare programs to their workers. However, the range of services and programs varied enormously and many firms continued to engage in these practices (Jacoby, 1997). After the World War II, employee health insurance and pension programs became standard practice in large corporations as components of modern human 
resource management. Clarence Walton and Howard Bowen and Archie Carroll (1999) attributed the modern conception of corporate social responsibility. Carl Kaysen (1957) coined the phrase of "the soulful corporation" to refer to more "responsible" large enterprise. Corporations became powerful social institutions with enormous potential as levers of public policy. Thus, in the 1960s began to treat the corporation as an instrument of social policy. The Civil Rights Act of 1964 established the Equal Employment Opportunity Commission in order to eliminate workplace discrimination while the Equal Employment Opportunity Act of 1972 provided the EEOC litigation authority (Whitman, 1999).General Motors published its first Public Interest Report in 1972, and by year 2005, 52 percent of the Fortune Global 250 largest firms produced corporate responsibility reports (KPMG, 2005). From 1995 to 1999, funds investing in "socially screened" firms increased from $\$ 162$ billion to $\$ 1.5$ trillion in assets (Fung, O'Rourke, and Sabel, 2001). Investor activism increased to prompt more ethical corporate action (Proffitt, 2001). CSR became an institution to deal with "stakeholder management" as a field and profession to manage employment relations (Dobbin and Sutton, 1998). India has a long history of paternalistic philanthropy. Kautilya in ancient India preached and promoted ethical principles while doing business. The concept of helping the poor and disadvantaged has been refered in ancient literature. However, during the pre-industrialized period philanthropy, religion and charity were the key drivers of CSR. During industrial period, the business owners also established temples, schools, higher education institutions and other infrastructure for public use (Earnest and Young- PHD,2013).

The term CSR itself came into common use in the early 1970s. The last decade of the twentieth century witnessed a shift in focus from charity and traditional philanthropy toward more direct engagement of business in mainstream development and concern for disadvantaged groups in the society. In India, there is a growing realization that business cannot succeed in isolation and social progress is necessary for sustainable growth. An ideal CSR practice has both ethical and philosophical dimensions, particularly in India 
where there exists a wide gap between sections of people in terms of income and standards as well socio-economic status (Bajpai, 2001). There is an increased focus and a changing policy environment to enable sustainable practices and increased participation in the socially inclusive practices. In the last decade, CSR has rapidly evolved in India with some companies focusing on strategic CSR initiatives to contribute toward nation building. Gradually, the companies in India started focusing on need-based initiatives aligned with the national priorities such as public health, education, livelihoods, water conservation and natural resource management.

Intensive national level deliberations on the potential role and responsibility of the corporate sector in contributing to address social issues were witnessed in the last decade. In its focus on persuading companies to participate in addressing social and developmental issues, not only as a part of their social responsibility but also their business practices, the National Voluntary Guidelines on Social, Environmental and Economic Responsibilities of Business Voluntary CSR guidelines create a common standard for how companies can improve their CSR efforts, especially with regard to sustainability. The adoption of a common set of standards creates an expectation that companies will strive to meet the guidelines, and can create peer and public pressure for companies failing to comply. Ministry of Corporate Affairs in order to provide companies with guidance in dealing with the expectations of inclusive growth and imperatives of climate change has laid down the guidelines. These guidelines are applicable to all businesses irrespective of size, sector or location. In the last decade, CSR has been a focus of all stakeholders including the government, corporate sector, media, customers, suppliers, employees and communities.

CSR has set the wheels in motion for increased contribution and more socially responsible behavior to lead to inclusive growth. Moreover, the above guidelines indicate that government emphasizes on CSR and engaging public and private companies to enhance their contribution toward reducing the gap between economic and social progress. CSR is relevant in the changing policy environment and 
also to meet business objectives. The Companies Act, 2013, stands to facilitate sustained flow of funds into social initiatives beyond the traditional "social" dimension of corporate social responsibility. Businesses can focus their attention towards two areas simultaneously: (a) drive their respective CSR programs; and (b) build an organization capable of transitioning from the by lanes of corporate social responsibility to a wider corporate responsibility. Corporate responsibility consists of social, environmental and financial responsibility. With India's enactment of the Companies Act, 2013, Indian businesses have to focus on corporate social responsibility to their business performance. The Act brings more Indian companies into the fold. Under this Act, any Indian company having a turnover of Rs. 10 billion (Rs. 1000 crore or about $\$ 161.3$ million), or more, or a net worth of Rs. 5 billion (Rs. 500 crore or about $\$ 80.6$ million) or more, or a net profit of Rs. 50 million (Rs. 5 crore or $\$ 8$ million) or more, must spend 2 percent of its average net profit in the preceding three years on CSR initiatives. The law also applies to foreign companies doing business in India. The CSR Rules, 2014 has listed a set of activities eligible under CSR such as: promotion of education, eradication of extreme hunger and poverty, combating HIV-AIDS, malaria and other diseases, reducing child mortality and improving maternal health, employment enhancing vocational skills, and such other matters as may be prescribed in future. The companies meeting the above-mentioned criteria have to form a committee dedicated to undertaking CSR initiatives in areas spelled out by the government.

\section{CSR Spending}

Indian Institute of Corporate Affairs has estimated that at least 6000 companies will have to adopt new CSR rules. It is apparent that 2 per cent mandate is likely to impact a wide range of Indian companies. During 2013-2014, larger CSR spending companies were reported to be Reliance Industries, ICICI Bank, Tata Steel, Sesa Sterlite and TCS. However, this spending as percentage of net profits was reported higher in case of Tata Motors (5.17 per cent) followed by Tata Steel (3.31 per cent), Reliance Industries (3.24 per cent) and Adani Enterprises (3.08 per cent) (Table No. 1). 
Table No. 1 : CSR Expenditure of India's Large Private Sector Companies

\begin{tabular}{|l|r|c|}
\hline \multicolumn{1}{|c|}{ Company } & $\begin{array}{c}\text { 2013-14 CSR } \\
\text { Spending } \\
\text { (\$ Million) }\end{array}$ & $\begin{array}{c}\text { CSR Spending as } \\
\text { Percentage of Net } \\
\text { Profit }\end{array}$ \\
\hline Reliance Industries & 119.88 & 3.24 \\
\hline Tata Motors & 2.84 & 5.17 \\
\hline Tata Steel & 34.7 & 3.31 \\
\hline Essar Oil & N/A & N/A \\
\hline Hindalco Industries & 5.28 & 1.81 \\
\hline Bharathi Airtel & 6.62 & 1.46 \\
\hline Larsen and Toubro & 12.6 & 1.40 \\
\hline TCS & 15.06 & 0.48 \\
\hline ICICI Bank & 80.59 & 2.00 \\
\hline Mahindra and Mahindra & 5.35 & 0.87 \\
\hline SesaSterlite & 28.32 & 1.40 \\
\hline Adani Enterprises & 0.9 & 3.08 \\
\hline Infosys & 1.47 & 0.09 \\
\hline JSW Steel & 4.42 & 2.00 \\
\hline HDFC Bank & 11.52 & 0.83 \\
\hline
\end{tabular}

Source: CSIS, 2015.

Although some studies (Singh and Agarwal 2013) have studied the types of CSR activities undertaken by Indian companies, By the year 2013, many firms had disclosed the activities undertaken by them, they could not disclosed the amount they spent on each activity. It has been observed that most of the firms have undertaken CSR expenditure on welfare of rural communities, especially around their areas of operation. As compared with developed countries where CSR activities are undertaken mainly in the area of environment, in India it is mainly undertaken in the social sector. After community development, education including skill development attracts the 
largest share of CSR expenditure. Health is also a major area where firms like to invest. The table gives an industry-wise breakup of the major CSR activities undertaken by each industry (Table No. 2).

Table No. 2 : Industry-wise Segregation of Major CSR Activities Undertaken by Firms in 2012-13.

\begin{tabular}{|l|c|c|c|c|c|}
\hline \multicolumn{1}{|c|}{ Industry } & Health & Education & $\begin{array}{c}\text { Community } \\
\text { Development } \\
\text { / Rural } \\
\text { Development }\end{array}$ & $\begin{array}{c}\text { Environ } \\
\text { ment }\end{array}$ & Total \\
\hline Oil and Gas & $23.50 \%$ & $35.29 \%$ & $29.41 \%$ & $11.76 \%$ & $100 \%$ \\
\hline Automobile & $40.00 \%$ & $10.00 \%$ & $40.00 \%$ & $10.00 \%$ & $100 \%$ \\
\hline $\begin{array}{l}\text { Consumer } \\
\text { Durables }\end{array}$ & $24.76 \%$ & $21.34 \%$ & $15.25 \%$ & $28.75 \%$ & $100 \%$ \\
\hline Iron \& Steel & $35.29 \%$ & $23.53 \%$ & $35.29 \%$ & $5.88 \%$ & $100 \%$ \\
\hline $\begin{array}{l}\text { Banking \& } \\
\text { Financial } \\
\text { Services }\end{array}$ & $8.57 \%$ & $20.00 \%$ & $48.57 \%$ & $35 \%$ & $100 \%$ \\
\hline Power & $10.00 \%$ & $10.00 \%$ & $45.00 \%$ & $35.00 \%$ & $100 \%$ \\
\hline Infrastructure & $8.35 \%$ & $30.55 \%$ & $44.44 \%$ & $16.66 \%$ & $100 \%$ \\
\hline Cement & $22.20 \%$ & $25.00 \%$ & $29.00 \%$ & $23.80 \%$ & $100 \%$ \\
\hline Paper \&Pulp & $19.90 \%$ & $24.10 \%$ & $18.00 \%$ & $38.00 \%$ & $100 \%$ \\
\hline $\begin{array}{l}\text { Pharmaceutic } \\
\text { al }\end{array}$ & $30.00 \%$ & $28.00 \%$ & $22.00 \%$ & $20.00 \%$ & $100 \%$ \\
\hline Source Cal & & & & & \\
\hline
\end{tabular}

Source: Calculated from the annual reports of the top 200 firms for the year 2012-13

The public sector undertakings had spending mostly on development of townships and community, with a special focus on education in $\mathrm{n}$ the oil and gas sector. However, they initiated CSR activities on community development in and around their areas of operation. This is because of the fact that communities living close to their area of operation are most affected by their production process activities. Hence the firms undertake CSR spending in order to reduce the negative effects of their production activities. Moreover, the firms are intending to build social relations in order to mitigate the negative consequences of their industrial activities. They organise health camps, which provide free medical check-ups to people. The Indian 
Oil Corporation runs mobile medical units in Mathura and has setup a nurse training institute in Digboi in Assam. It has also spent a lot on the school education of children who live near their plants and in their townships. The Steel Authority of India Limited has invested in health and education infrastructure for the welfare of its employees. Many firms spend on skill development programmes for building human capital and creating better employment prospects for local people. The firms support the school education of the children living in the nearby areas and provide scholarships for higher education as well. Banks and financial institutions spend mainly on priority sector areas. They count the 40 percent mandatory priority sector lending as a part of their CSR activities.

Thus, they focus on mainly financial inclusion, financial literacy, SHGs formation, bank linkages and credit to poor communities. However, banks such as Jammu and Kashmir Bank undertake activities other than priority sector lending also. They support schools and provide funds for meeting educational expenses. Studies have revealed that banks are spending more on education and environment in order to strengthen their brand image and increasing consumer satisfaction (Narwal 2007). Large banks are focussing on more CSR activities for better market performance, while smaller banks intend to increase their CSR initiatives in order to build strong relationships with its stakeholders (Narwal 2007). Singh and Agrawal (2011) found that Indian banks differ in their CSR orientation with respect to their ownership structure, number of employees, and date of its incorporation. There is a significant difference in orientation in the areas of environment and rural development and community welfare. Indian banks no longer see CSR as charity, but they see it as a way of building their image and marketing their products. Only one company managed to spend the prescribed CSR spend among 17 Banking and Finance sector companies. Almost 50 percent of the companies could not spend even half of the prescribed CSR spend. While Mahindra \& Mahindra Financial Services managed to spend all of the prescribed CSR spend while DHFL could spend only 3.9 percent of the prescribed CSR making it to the last spot in the list (Table No. 3) 
Table No. 3 : CSR Spending in Banking \& Finance Sector Companies (2015)

\begin{tabular}{|l|c|c|c|}
\hline \multicolumn{1}{|c|}{ Company } & $\begin{array}{c}\text { Prescribed } \\
\text { CSR Spend }\end{array}$ & $\begin{array}{c}\text { Actual CSR } \\
\text { Spend }\end{array}$ & $\begin{array}{c}\text { Percentage } \\
\text { of the } \\
\text { Prescribed }\end{array}$ \\
\hline $\begin{array}{l}\text { Mahindra \& Mahindra } \\
\text { Financial Services Ltd }\end{array}$ & 24.87 & 24.87 & $100.00 \%$ \\
\hline IDFC Limited & 47 & 46.5 & $98.9 \%$ \\
\hline Axis Bank Ltd & 133.77 & 123.22 & $92.1 \%$ \\
\hline ICICI Bank Ltd & 172 & 156 & $90.7 \%$ \\
\hline $\begin{array}{l}\text { Bajaj Holdings and } \\
\text { Investment Ltd }\end{array}$ & 5.47 & 4 & $73.1 \%$ \\
\hline Bajaj Finserv Ltd & 1.48 & 1 & $67.6 \%$ \\
\hline $\begin{array}{l}\text { Cholamandalam } \\
\text { Investment \& Finance } \\
\text { Co. Ltd }\end{array}$ & 8.6 & 5.73 & $66.6 \%$ \\
\hline $\begin{array}{l}\text { SREI Infrastructure } \\
\text { Finance Ltd }\end{array}$ & 2.26 & 1.38 & $61.1 \%$ \\
\hline HDFC Bank Ltd & 197.13 & 118.55 & $60.1 \%$ \\
\hline $\begin{array}{l}\text { Housing Development } \\
\text { Finance Corp }\end{array}$ & 9.93 & 4.49 & $45.2 \%$ \\
\hline Manappuram Finance Ltd & 10.173 & 4.46 & $643.8 \%$ \\
\hline Yes Bank Ltd & 38.02 & 15.71 & $41.3 \%$ \\
\hline Capital First Ltd & 1.93 & 0.75 & $38.9 \%$ \\
\hline Magma Fincorp Ltd & 3.78 & 1.26 & $33.3 \%$ \\
\hline Kotak Mahindra Bank Ltd & 39.2 & 11.97 & $30.5 \%$ \\
\hline $\begin{array}{l}\text { Shriram Transport Finance } \\
\text { Co Ltd }\end{array}$ & 38.15 & 6.924 & $18.1 \%$ \\
\hline $\begin{array}{l}\text { Dewan Housing Finance } \\
\text { Corp Ltd }\end{array}$ & 11.58 & 0.45 & $3.9 \%$ \\
\hline Source MinistryofCorporat & & & \\
\hline
\end{tabular}

Source: Ministry of Corporate Affairs, Government of India

Looking at the five largest public sector undertakings (Table No. 4), it appears that mandate will impact this group of companies to a large extent. None of them report a level of CSR spending above 2 per cent 
mandate. Largest CSR spending public sector undertaking is reported to be ONGC followed by SBI and Indian Oil Corporation. All these companies have CSR spending less than 2 percent of their net profits. Indian Institute of Corporate Affairs estimates that currently average CSR spending across India is around 1 per cent.

\section{Table No. 4 : CSR Expenditure of India's Large Public Sector}

Companies

\begin{tabular}{|l|r|c|}
\hline \multicolumn{1}{|c|}{ Company } & $\begin{array}{c}\text { 2013-14 CSR } \\
\text { Spending } \\
\text { (\$ Million) }\end{array}$ & $\begin{array}{c}\text { CSR Spending as } \\
\text { Percentage of Net } \\
\text { Profit }\end{array}$ \\
\hline Indian Oil Corporation & 13.7 & 1.20 \\
\hline Bharat Petroleum Corporation & 5.59 & 0.85 \\
\hline $\begin{array}{l}\text { Hindustan Petroleum } \\
\text { Corporation }\end{array}$ & 3.86 & 1.37 \\
\hline State Bank of India & 24.26 & 1.37 \\
\hline $\begin{array}{l}\text { Oil \& Natural Gas } \\
\text { Corporation }\end{array}$ & 55.49 & 1.55 \\
\hline
\end{tabular}

Source: CSIS, 2015.

About 34 percent of the top 300 firms in India are implementing CSR activities through their own foundations or trusts. They serve the society through various measures like community development, rural development, etc. About 19 percent of the companies do organise camps for free medical check-up, blood donation and education for farmers and school children in the rural areas. Around 30 percent of the firms and companies do collaborate with civil society organisations to carry out their CSR activities. Tata Motors has collaborated with a number of industrial training institutes to conduct skill development programmes. Some of the firms have collaborated with government schools for assisting in mid-day meal programmes. About 5 percent of the companies/ firms have adopted environmentally sustainable methods for production. These firms are mainly environmentally polluting industries such as paper and pulp as well as chemical industries. About 12 percent of the firms provide donations to local schools and hospitals. Mostly banks donate 
medical equipments and school books to local hospitals and schools.

CSR expenditure in north-east region by ONGC is shown in Table 5. ONGC is one of the large Central PSU in oil sector. ONGC mainly works in Assam and Tripura in North-East region. ONGC has a larger share under CSR expenditure. It mainly allocates CSR funds for sanitation, skill development, environment protection, promotion of sports and games, community health, education and medical assistance to health centres in North-East region. About $3 / 4^{\text {th }} \mathrm{CSR}$ expenditure by ONGC constituted the expenditure for marginalized communities including Scheduled Castes, Scheduled Tribes and other weaker sections. During the period of 2013-14 to 2015-16, Rs. 819.65 crores were allocated under CSR for empowerment of marginalized groups and out of them, Rs. 94.79 crores were allocated under CSR in North-East region. The share of CSR expenditure in North-East region constituted 26.75 per cent in 2013-14 which decline to 16.05 per cent in 2015-16.

Table No. 5 : CSR Expenditure in North-East Region by ONGC

(Rs. Lakh)

\begin{tabular}{|l|c|c|c|}
\hline \multicolumn{1}{|c|}{ State } & $\mathbf{2 0 1 3 - 1 4}$ & $\mathbf{2 0 1 4 - 1 5}$ & $\mathbf{2 0 1 5 - 1 6}$ \\
\hline Arunachal Pradesh & 6.68 & 1.00 & 185.31 \\
\hline Assam & 1174.86 & 1561.20 & 2900.43 \\
\hline Manipur & 12.62 & 13.00 & 1.00 \\
\hline Meghalaya & 3.74 & 258.00 & 1316.00 \\
\hline Nagaland & 28.11 & 0.00 & 0.00 \\
\hline Mizoram & 88.45 & 1.0 & 2.00 \\
\hline Sikkim & 6.45 & 0.00 & 1.00 \\
\hline Tripura & 761.00 & 460.79 & 688.28 \\
\hline Total & $\mathbf{2 0 8 1 . 9 1}$ & $\mathbf{2 2 9 4 . 9 9}$ & $\mathbf{5 1 0 2 . 0 2}$ \\
\hline India(SC/ST/Weaker Section) & $\mathbf{7 7 8 1 . 4 6}$ & $\mathbf{1 3 6 7 2 . 1 7}$ & $\mathbf{3 1 7 7 8 . 8 0}$ \\
\hline India(Grand Total) & $\mathbf{1 8 3 0 4 . 2 8}$ & $\mathbf{2 1 5 6 0 . 5 6}$ & $\mathbf{4 2 0 9 9 . 9 9}$ \\
\hline
\end{tabular}

Source: Annual Report, ONGC. 
CSR expenditure in Hindustan Petroleum is shown in Table No. 6. CSR expenditure by Hindustan Petroleum has increased by 202.24 per cent during 2013-14 to 2015-16. About $1 / 4^{\text {th }}$ CSR expenditure in 2015-16 was reported for LPG connections to poor while about 23 per cent fund was allocated for education and child care. Sanitation, health care and skill development accounted for a larger share in CSR expenditure by Hindustan Petroleum during the year.

Table No. 6 : CSR Expenditure by Hindustan Petroleum

\begin{tabular}{|l|r|r|r|}
\hline \multicolumn{1}{|c|}{ Particulars } & $\mathbf{2 0 1 3 - 1 4}$ & \multicolumn{1}{c|}{$\mathbf{2 0 1 4 - 1 5}$} & \multicolumn{1}{c|}{ 2015-16 } \\
\hline Education and Child Care & 983.01 & 1080.42 & 1632.48 \\
\hline Health Care & 416.39 & 894.65 & 1164.23 \\
\hline Skill Development & 228.86 & 288.03 & 505.17 \\
\hline $\begin{array}{l}\text { Environment and Community } \\
\text { Development }\end{array}$ & 283.83 & 182.54 & 437.14 \\
\hline Sports and Games & - & 84.77 & 67.81 \\
\hline Disaster Management & 100.00 & - & - \\
\hline Swachh Bharat Abhiyan & - & 63.13 & 505.71 \\
\hline Swachch Bharat Vidyalaya & - & 813.91 & 1075.96 \\
\hline LPG Connections to Poor & 362.00 & - & 1787.00 \\
\hline Total & $\mathbf{2 3 7 4 . 0 9}$ & $\mathbf{3 4 0 7 . 4 5}$ & $\mathbf{7 1 7 5 . 5 1}$ \\
\hline
\end{tabular}

Source: Annual Report, Hindustan Petroleum.

Table No. 7 : CSR Fund Utilized by Hindustan Petroleum in North-East Region

(Rs. Lakh)

\begin{tabular}{|l|r|r|r|}
\hline \multicolumn{1}{|c|}{ State } & 2013-14 & 2014-15 & 2015-16 \\
\hline Arunachal Pradesh & - & - & 14 \\
\hline Assam & 45 & 89 & 26 \\
\hline Manipur & - & 13 & 11 \\
\hline Mizoram & - & - & 7 \\
\hline Total & $\mathbf{4 5}$ & $\mathbf{1 0 2}$ & $\mathbf{5 8}$ \\
\hline India & $\mathbf{2 3 7 4}$ & $\mathbf{3 4 0 7}$ & $\mathbf{7 1 7 6}$ \\
\hline
\end{tabular}

Source: Annual Report, Hindustan Petroleum. 
CSR fund utilized by Hindustan Petroleum in North-East region is shown in Table No. 7. CSR expenditure in North-East region constituted 1.89 per cent in 2013-14 which increased to about 3 per cent in 2014-15 and dropped to 0.8 per cent in 2015-16. However, there has been increase of 28.88 per cent during the period 2013-14 to 2015-16.

CSR fund utilized for empowerment of SC/ST and weaker sections by Hindustan Petroleum is shown in Table No. 8. There has been increase of 178.33 per cent in CSR expenditure for empowerment of SC/ST and weaker sections by Hindustan Petroleum during 2013-14 to 2015-16. CSR expenditure in North-East region constituted 2 per cent in 2015-16 while it was reported 1.22 per cent during 2013-14.

Table No. 8 : CSR Fund Utilized for Empowerment of SC/ST and Weaker Sections by Hindustan Petroleum

(Rs. Lakh)

\begin{tabular}{|l|r|r|r|}
\hline \multicolumn{1}{|c|}{ State } & $\mathbf{2 0 1 3 - 1 4}$ & $\mathbf{2 0 1 4 - 1 5}$ & \multicolumn{1}{c|}{$\mathbf{2 0 1 5}-16$} \\
\hline Arunachal Pradesh & - & - & 13.73 \\
\hline Assam & 9.08 & - & 17.75 \\
\hline Manipur & - & 12.58 & 10.83 \\
\hline Mizoram & - & - & 7.02 \\
\hline Total & $\mathbf{9 . 0 8}$ & $\mathbf{1 2 . 5 8}$ & $\mathbf{4 9 . 3 3}$ \\
\hline India & $\mathbf{7 4 5 . 2 8}$ & $\mathbf{1 1 8 4 . 3 2}$ & $\mathbf{2 0 7 4 . 4 1}$ \\
\hline
\end{tabular}

Source: Annual Report, Hindustan Petroleum.

Table No. 9 : CSR Fund Allocated by GAIL in North-East Region During 2013-14

(Rs. Lakh)

\begin{tabular}{|l|c|c|r|}
\hline \multicolumn{1}{|c|}{ State } & District & Area & \multicolumn{1}{c|}{ CSR Fund } \\
\hline Assam & Sibsagar & Skill Development & 4.61 \\
\hline Assam & Sibsagar & Skill Development & 43.73 \\
\hline Tripura & West & Skill Development & 4.61 \\
\hline Tripura & West & Drinking Water & 33.55 \\
\hline Tripura & West & Skill Development & 44.73 \\
\hline
\end{tabular}

Source: Annual Report, GAIL. 
CSR fund allocated by GAIL in North-East region is shown in Table No. 9. GAIL has also allocated substantial fund under CSR in North-East region mainly in Assam and Tripura.

CSR expenditure by Indian Oil Corporation Ltd. is shown in Table No. 10. There has been increase of 165 per cent in CSR fund during the period of 2013-14 to 2016-17. During the year of 201516, Rs. 28.22 crores were allocated in North-East region and out of them, Rs. 26.92 crores were allocated for Assam.. CSR expenditure by Indian Oil Corporation Ltd. in North-East region constituted for 18 per cent against total CSR expenditure by the organization.

\section{Table No. 10 : CSR Expenditure by Indian Oil Corporation Ltd.}

\begin{tabular}{|l|r|}
\hline \multicolumn{1}{|c|}{ Year } & \multicolumn{1}{|c|}{ CSR Fund } \\
\hline $2013-14$ & 81.91 \\
\hline $2014-15$ & 113.79 \\
\hline $2015-16$ & 156.68 \\
\hline $2016-17$ & 217.10 \\
\hline Total & $\mathbf{5 6 9 . 4 8}$ \\
\hline
\end{tabular}

Source: Annual Report, IOCL

CSR expenditure by BCPL during 2014-15 is shown in Table No. 11. BCPL has substantial amount on CSR allocation however, expenditure against outlay has been reported to be low. On an average, Rs. 1 crore is being allocated per annum under CSR mainly for the North-East region by the organization. During 2014-15, about half of the amount was spent on sanitation including drinking water.

Table No. 11 : CSR Expenditure by BCPL During 2014-15

(Rs. Lakh)

\begin{tabular}{|l|r|c|}
\hline \multicolumn{1}{|c|}{ Particular } & CSR Fund & Percentage \\
\hline $\begin{array}{l}\text { Community Development and } \\
\text { Infrastructure }\end{array}$ & 30.38 & 33.73 \\
\hline Drinking Water and Sanitation & 42.07 & 46.71 \\
\hline Education and Literacy & 17.61 & 19.55 \\
\hline Total & $\mathbf{9 0 . 0 6}$ & $\mathbf{1 0 0 . 0 0}$ \\
\hline
\end{tabular}

Source : Annual Report, BCPL 
CSR expenditure by BCPL during 2015-16 is shown in Table No. 12. During 2015-16, vocational education constituted 26.45 per cent against cumulative expenditure under CSR by the organization. Cumulative expenditure was recorded high for natural calamities followed by sanitation, rural development, education and rural sports.

Table No .12 : CSR Expenditure by BCPL During 2015-16

(Rs. Lakh)

\begin{tabular}{|l|r|r|c|}
\hline \multicolumn{1}{|c|}{ Particular } & Outlay & $\begin{array}{r}\text { Cumulative } \\
\text { Expenditure }\end{array}$ & Percentage \\
\hline Skill Development & 24.77 & 24.77 & 4.65 \\
\hline Vocational Education & 40.0 & 141.00 & 26.45 \\
\hline Rural Development & 9.65 & 77.36 & 14.51 \\
\hline $\begin{array}{l}\text { National Heritage } \\
\text { Conservation }\end{array}$ & 4.65 & 4.44 & 0.83 \\
\hline Rural Sports & 2.0 & 66.42 & 12.46 \\
\hline Education & 5.00 & 76.42 & 14.33 \\
\hline Sanitation & 10.00 & 86.42 & 16.21 \\
\hline Natural Calamity & 1.43 & 97.88 & 18.36 \\
\hline Total & $\mathbf{9 7 . 5 0}$ & $\mathbf{5 3 3 . 1 3}$ & $\mathbf{1 0 0 . 0 0}$ \\
\hline
\end{tabular}

Source: Annual Report, $B C P L$

CSR expenditure by NRL is shown in Table No. 13. Numaligarh Refinery Ltd was setup in 1985 in Golaghat district of Assam after Assam Accord by Government of India. During 2013-14, 2016-17,

Table No. 13 : CSR Expenditure by NRL

(Rs. Lakh)

\begin{tabular}{|l|r|r|}
\hline \multicolumn{1}{|c|}{ Year } & \multicolumn{1}{|c|}{ Outlay } & \multicolumn{1}{c|}{ Expenditure } \\
\hline $2013-14$ & 551.00 & 529.00 \\
\hline $2014-15$ & 762.30 & 762.45 \\
\hline $2015-16$ & 1426.25 & 1157.55 \\
\hline $2016-17$ & 4120.15 & 2059.61 \\
\hline Total & $\mathbf{6 8 5 9 . 7 0}$ & $\mathbf{4 5 1 8 . 6 1}$ \\
\hline
\end{tabular}

Source: Annual Report, NRL. 
Rs. 6859.70 lakh were allocated under CSR by the organization. There has been an increase of 3.89 times over the period of 2013-14 to 2016-17. The company mainly works in North-East region. The CSR heads were reported mainly on education, livelihood development, community development, infrastructure development and promotion of crafts, arts and culture.

Table No .14 : CSR Expenditure by Oil India Ltd.

(Rs. Crore)

\begin{tabular}{|l|r|r|}
\hline \multicolumn{1}{|c|}{ Year } & Expenditure & Expenditure in NER \\
\hline $2013-14$ & 72.89 & - \\
\hline $2014-15$ & 133.31 & 116.0 \\
\hline $2015-16$ & 92.21 & 42.52 \\
\hline Total & $\mathbf{2 9 8 . 4 1}$ & - \\
\hline
\end{tabular}

Source: Annual Report, Oil India Ltd.

CSR expenditure by Oil India Ltd. is shown in Table No. 14. During the period of 2013-14 to 2015-16, Oil India Ltd allocated Rs. 300 crores under CSR and out of them, more than half of the CSR funds were allocated for North-East region.

The CSR activities are being implemented through building network and collaboration with voluntary organizations, community based organizations and even directly providing support to community. The major target groups covered under CSR initiatives are poor, marginalized, deprived and backward population. The thematic issues of CSR initiatives are being decided by the mandate of corporate houses, companies and business enterprises however, it also depends on the demand from the community. There has been significant increase in the number of beneficiaries under CSR initiatives during last 3 years. The corporate houses and companies further revealed that they are concentrating their CSR activities in their operational area and also on the basis of demand generated by their stakeholders. Most of the organizations reported that they have separate allocation of funds or CSR corpus for implementation of CSR activities. 


\section{Suggestions}

- The Companies Act, 2013, has made provision for penalty for not filing of details of CSR, but there is no penal action for noperformance of a company. Thus, there should be a clarification for penal action. Clear cut statutory guidelines or policy directives are to be issued in order to give a definitive direction to CSR initiatives of the companies

- Awareness creating among the public in general regarding CSR activities is necessary besides improving communication between the companies involved in CSR and the general public at the grassroots is also required. Capacity building of nongovernmental organizations is essential as there is dearth of trained and efficient civil society organizations which can effectively contribute to the ongoing CSR activities initiated by corporate houses. .

- In order to ensure successful implementation of CSR activities socially committed and sound non-governmental organizations will be required. Broader outlook towards CSR initiatives is necessary as NGOs and Government agencies usually possess narrow perception towards the CSR initiatives as donor-driven.

- The role of media in highlighting best practices of CSR initiatives is important. Media may also play an important role in sensitization of public at large civil society organisations in particular in improving the social status of marginalized and poor communities. It is the need of hour to build consensus amongst implementing agencies regarding CSR projects in order to avoid duplication of CSR initiatives in the same locations.

- The Corporate houses, private organizations and industries should give the priority on the national agenda of social activities however, education, poverty alleviation programmes, employment generation, livelihood development etc based on the local needs should be focused in CSR initiatives.

- CSR must be separated from the core principles of 
organizational management such as employee welfare, brand building, profit maximization, building relations with stakeholders etc. Government must bring under its purview of industries them under statute in the lines of Section 135 and Schedule VI of the Companies Act, 2013.

- Corporate houses, private organizations and industries should look towards CSR as a creative opportunity to strengthen their businesses while contributing in social investment for development of society. CSR should be treated as central to overall strategies in business development and strengthening relations with stakeholders.

- The CSR projects should be integrated with main business agenda of company as community development is a very important feature of the CSR agenda. In order to exploit their full potential, community development projects need to be coherently planned, implemented and monitored, in partnership with NGOs and local government.

- Interaction between NGOs and companies, industries, private organizations and corporate houses needs to be strengthened by the through stronger NGO network, engagement in implementing community development projects and capacitybuilding relating to CSR issues and by bringing together different networks and players from both companies and stakeholders. In order to address the issue of building effective partnerships amongst all the important stakeholders for the implementation of CSR initiatives, suitable measures should be undertaken.

- Government should adopt pro active role in fostering the CSR through making the system more transparent, accountable and socially responsible. The corporate houses, companies and business enterprises must be mobilized for social investment and collaboration with local governments and other government agencies for empowering poor, marginalized and backward communities besides alleviation of poverty. Corporate social responsibility must be seen as an effective 
instrument in promoting public private partnership in infrastructure development, delivery of services and improving governance.

\section{References}

Bajpai, G.N. (2001), Corporate Social Responsibility in India and Europe: Cross Cultural Perspective, www.ficci.com

Bowen,H.R.(1953).Social responsibilities ofthebusinessman.NewYork: Harper\&Row

Carroll, AB, (1999) 'Corporate social responsibility: Evolution of a definitional construct 'Business and Society, 38(3), 268-95.

Carroll, AB (1979), A Three-Dimensional Conceptual Model OfCorporate Social Performance, Academy of Management Review, vol. 4.

Cochran, P. (2007), The Evolution Of Corporate Social Responsibility, Business Horizons, Vol.50 No. 2.

EY-PHD (2013), Corporate Social Responsibility in India, Ernest and Young, New Delhi..

Gulati, J. (2005), CSR Debate in India - From Philanthropy to Public Private People Partnership, IN Corporate Social Responsibility: Concept and Cases Edited by Baxi, C.V.Ajit Prasad, Excel Books, New Delhi.

IGDR (2015), Corporate Social Responsibility in India: An Effort to Bridge the Welfare Gap, Indira Gandhi Institute for Development Research, Bombay

Jacoby, S.M., (1997), Modern Manors: Welfare Capitalism Since the New Deal, Princeton: Princeton University Press..

Kaysen, C., (1957), "The Social Significance of the Modern Corporation," American Economic Review (Papers and Proceedings), 47(2).

KPMG (2005), International Survey of Corporate Responsibility Reporting, New Delhi.

Mohan, A. (2001): Corporate Citizenship: Perspectives from India, in: Journal of Corporate Citizenship 2.

Pollard, S., (1965), The Genesis of Modern Management: A Study of the Industrial Revolution in Great Britain, London: Edward Arnold.

Prahalad C K and Hamel G. (1990). The Core Competence and the Corporation. Harvard Business Review, Vol. 68, No. 3, pp. 71-91.

Proffitt, W.T., Jr., (2001), The Evolution of Institutional Investor Identity: Social Mobilization in the Shareholder Activism Field, Unpublished 
Dissertation, Northwestern University.

Sethi P. (1975) Dimensions of Corporate Social Performance: An Analytical Framework California Management Review 17(3), 58-64

Singh, R and Aggarwal, S (2013): "Corporate Social Responsibility Impact: Approach to measure social impact using CSR Impact Index", Working Paper Series No. 729, Indian Institute of Management Calcutta

Walton, C. C. (1967). Corporate social responsibilities. Belmont, CA: Wadsworth.

Wartick, S. and P. L. Cochran: (1985,) 'The Evolution of Corporate Social Performance Model', Academy of Management Review 10(4), 758-769.

Whitman, M V..N., (1999), New World, New Rules: The Changing Role of the American Corporation, Boston: Harvard Business School Press. 